\title{
Self-perception of the objective, object and work products of Physical Education Professionals belonging to the Academia da Saúde Program
}

\author{
Autopercepção acerca do objetivo, objeto e produtos do trabalho dos \\ Profissionais de Educação Física que atuam no Programa Academia da Saúde
}

Flávio Renato Barros da Guarda1,2, Rafaela Niels da Silva3,4, Wallacy Milton do Nascimento Feitosa 1,4, Joni Marcio de Farias Pedro Miguel dos Santos Neto', José Luiz do Amaral Correia de Araújo Júnior

\begin{abstract}
Work processes begin by establishing intervention objectives, followed by defining the object that professionals seek to transform and the availability and means of performing tasks and achieving the expected products. The aim of this study was to assess the perception of physical education professionals regarding the purpose of their activities, the object of their professional intervention and the products of their work in the Academia da Saúde (Health Academy) Program. To that end, we carried out a qualitative study with 18 professionals working in the Metropolitan Region of Recife, Pernambuco state, in northeastern Brazil. Content analysis of the interviews used the condensation of meaning technique. It was found that these workers identified health promotion as a goal of their actions, individuals and communities as objects of their intervention, and improvement of physical and functional performance, social interaction and biopsychosocial benefits as the main products of their work in the program. On the other hand, perception of health promotion focuses on changing behavior, and lack of coordination in program activities with Basic Health Care teams demonstrates a worrisome move away from proposals for intersectoral and organizational multidisciplinary work processes with a view to comprehensive care in the National Health System (SUS).
\end{abstract}

\section{Keywords}

Physical Education and Training; National Health System; Professional Practice; Work process; Human Resources for Health.

\section{Resumo}

Processos de trabalho iniciam-se com o estabelecimento dos objetivos da intervenção, seguido pela definição do objeto sobre o qual o profissional irá desenvolver sua ação transformadora e pela disponibilidade e forma de utilização dos meios para a realização das tarefas e alcance dos produtos esperados. A finalidade deste estudo é conhecer a percepção dos profissionais de Educação Física sobre o objetivo das suas atividades, o objeto de sua intervenção profissional e os produtos do seu trabalho no Programa Academia da Saúde. Para tanto, realizou-se um estudo de abordagem qualitativa com 18 profissionais que atuam na Região Metropolitana do Recife. A análise do conteúdo das entrevistas utilizou a técnica da Condensação de Significados. Verificou-se que esses trabalhadores identificaram a promoção da saúde como objetivo das suas ações $e$ os indivíduos e comunidades como objetos da sua intervenção, além de descrevem a melhoria do desempenho físico/funcional, a interação social e os benefícios biopsicossociais como os principais produtos do trabalho no programa. Por outro lado, verifica-se que a percepção do conceito de promoção da saúde encontra-se focada na mudança de comportamentos, e que a falta de articulação das ações do programa com as equipes da Atenção Primária pode comprometer o alcance da interdisciplinaridade e da organização de processos de trabalho multiprofissionais com vistas à integralidade do cuidado no Sistema Único de Saúde.

\section{Palavras-chave}

Educação Física e treinamento; Sistema Único de Saúde; Atuação profissional; Processo de trabalho; Recursos bumanos em saúde.
1 Fundação Oswaldo Cruz / Centro de Pesquisas Aggeu Magalhães - Núcleo de Estudos em Saúde Coletiva - Recife/PE - Brazil

2 Universidade Federal de Pernambuco - Centro Acadêmico de Vitória - Vitória de Santo Antão/PE - Brazil

3 Universidade Federal de Pernambuco - Departamento de Educação Física - Recife/ PE - Brazil

4 Associação Caruaruense de Ensino Superior

5 Universidade do Extremo Sul Catarinense - UNESC

\section{Introduction}

Incorporating Physical Education Professionals (PEP) into the National Health System was achieved by creating Family Health Support Centers (FHSC) and implementing the Academia da Saúde Program (ASP), which interacts with other professional health categories with the aim of integrating actions and 
services ${ }^{1}$. This, however, requires these professionals to have a body of knowledge that qualifies them to intervene in the constraints and determinants of the health-disease process, demanding that the profiles of both PEPs and the other health professions be aligned with the characteristics and needs of interdisciplinary work ${ }^{2}$.

In this respect, the ASP was instituted by the Ministry of Health in 2011 to promote health, care production and healthy lifestyles through centers with good infrastructure and qualified professionals ${ }^{3}$.

Among the specific objectives of the program established under the Ministerial Decree of $2013^{3}$ is to increase the physical activity level of the population. To that end, interventions by PEPs are crucial, given that these professionals are required to act on the different ways of manifesting physical activity in different domains and contexts ${ }^{4}$.

Intervention by PEPs at the program centers requires the selection and mobilization of Physical Education knowledge, in addition to the ability to integrate this knowledge with that developed by other actors in the health care process (professionals, users, administrators and the remaining sectors) through multiprofessional teamwork ${ }^{5}$.

This body of knowledge, the instruments and means used to organize and provide individual and collective services characterize the health care process ${ }^{6}$.

All work processes are conducted by seeking to reach a number of predetermined goals and are therefore governed by their objective/intention and criteria, with parameters established as a function of this objective ${ }^{7}$.

These objectives are expressed in the goals that reflect the projected results required to meet the needs and expectations of individuals, in line with their social organization at a given moment in history ${ }^{7}$. Therefore, the work process is characterized by the intentional actions of individuals, with the aim of changing reality by transforming objects using different means to achieve these ends ${ }^{6}$.

The Metropolitan Region of Recife (MRR), the setting of this study, contains about half of the physical education professionals and ASP centers in Pernambuco state $^{8}$. In this respect, assessing the perception of PEPs about their work objectives in the Program may reveal: i) the objects that these workers aim to transform; b) the means to achieve the proposed objectives, and; c) the products generated from this work.

Moreover, knowledge of the perception that PEPs have regarding the objectives of their work may be an important tool for analyzing work processes as well as monitoring and assessing the ASP. However, there are no literature studies that analyze this perception.

The aim of this study was to assess the perception of Physical Education Professionals in the Metropolitan Region of Recife about the objective, object of their professional intervention and the products of their work in the Academia da Saúde Program.

\section{Methods}

This qualitative study was conducted with Physical Education professionals enrolled in the Academia da Saúde Program in the Metropolitan Region of Recife, which contains $45.16 \%$ of the centers in Pernambuco state. A qualitative approach was selected because it is well suited to this type of study, since this method could contribute to a detailed assessment of the object of this research in a setting in which the actions occur, providing a thorough and flexible description of the data, 
in addition to determining how the problem manifests itself on a daily basis and reflects the perspective of participants?

Data collection involved a semistructured interview, in order to increase understanding of the issue ${ }^{10}$. The interview contained questions on the following: i) the objective of the professionals' work in the ASP; ii) the means to achieve these objectives; iii) the products generated by this work; iv) how the professionals' work contributes to the Family Health Strategy, and; v) the professionals' perception of health promotion.

All the municipalities with centers operating in the MRR were selected. In order to randomly select professionals to be interviewed, with no intention of it being representative of the PEP population, at least one professional per center was drawn from a list of professionals and their respective work places and shifts in each municipality, resulting in 20 of them being invited to take part in the study (Table 1).

TABLE 1 - Distribution of professionals that work at Academia da Saúde Program centers in the Metropolitan Region of Recife and the individuals randomly drawn to participate in the study.

\begin{tabular}{lccc}
\hline Municipality & $\begin{array}{c}\text { No. of centers in } \\
\text { operation }\end{array}$ & $\begin{array}{c}\text { No. of professionals } \\
\text { enrolled in the centers }\end{array}$ & $\begin{array}{c}\text { No. of professionals } \\
\text { selected }\end{array}$ \\
\hline Abreu e Lima & 01 & 01 & 01 \\
\hline Cabo de Santo Agostinho & 02 & 04 & 02 \\
\hline Jaboatão dos Guararapes & 04 & 01 & 01 \\
\hline Olinda & 01 & 01 & 01 \\
\hline Recife & 37 & 149 & 15 \\
\hline
\end{tabular}

Source: Department of Health of Pernambuco state. Note: Table created by the authors based on data obtained from the Department of Health of Pernambuco state.

The municipality of Recife has 37 centers, distributed in its six Sanitary Districts. Two PEPs were drawn from different shifts (morning and afternoon), by Sanitary District. In Districts with the largest number of centers, three professionals were interviewed, totaling 15 individuals.

The interviews were conducted between July and August 2014, after participant authorization. All the responses were recorded and transcribed. Despite saturation of responses, it was decided to interview all the professionals, in an attempt to identify distinct impressions, even in the final interviews.

The Condensation of Meanings ${ }^{11}$ technique, which analyzes excerpts of the interview related to a specific study question, was used for content analysis of the interviews. These are collected and condensed into a chart of natural units of the meanings of the subjects' responses in a column on the left. The central issues related to these units constitute conceptual categories and are placed in a column on the right; below these columns is an essential description of the question analyzed, as demonstrated in Figure 1.

\begin{tabular}{l}
\hline Condensation of Meanings Interview n³ \\
\hline Question from study no. 1 (In your opinion what is the objective of your work?) \\
\hline Natural Units of Analysis (from the interview) Central Issues \\
\hline $\begin{array}{l}\text { The objective of the work is to instruct users regar- } \\
\text { ding a healthy lifestyle; encourage physical activity } \\
\text { and physical exercise as well (...) }\end{array}$ \\
\hline $\begin{array}{l}\text { Essential description of research question no. 1: The professional describes instruction regarding health-related } \\
\text { behaviors and encouragement to engage in physical activities as objectives of his work, with the aim of } \\
\text { improving individual health. }\end{array}$
\end{tabular}

FIGURE 1 - The natural meaning of units and their central issues. Source: Based on Giorgi apud Kvale ${ }^{11}$. 
The discourses were analyzed, complying with the following qualitative validity criteria proposed by Oliveira $(2008)^{12}$ : completeness, homogeneity, exclusiveness, objectivity and adequacy or pertinence. This stage involved the description, systematization, comparison and interpretation of the significant elements of the discourses, in order to relate them to the study object, its theoretical model and the analytical findings of the research, to identify the categories of analysis ${ }^{10}$.

This study is part of a doctoral project developed by the first author entitled: "Analysis of the work processes of Physical Education professionals enrolled in the Academia da Saúde Program in the Metropolitan Region of Recife". In order to guarantee anonymity, all the individuals interviewed were identified by codes, advised of the procedures and gave their informed consent. The project was approved by the Research Ethics Committee of Fiocruz Pernambuco, under Protocol no. 688.676, in accordance with National Health Council resolution no. 466 of December 12, 2012.

\section{Results}

Two professionals (one from Recife and the other from Jaboatão dos Guararapes) declined to be interviewed. Thus, only 18 of the 20 professionals drawn for this study were considered in the results.

\section{Perception of program objectives}

Analysis of the interviews showed that the professionals reported health promotion and quality of life as the objectives of their work, focusing on encouraging physical activities, as can be observed in the following statements:

"My work is to promote health by using the Physical Activity Strategy" (PEP 1).

"The objective is to promote health and the dissemination of physical activities in public spaces in order to contribute to the promotion of user health". (PEP 8).

"The objective of my work is to promote health. How? By making it possible for people to engage in physical activity, and these physical activities can include stretching, aerobic exercises, resistance exercises, games and leisure activities" (PEP 3).

On the other hand, some professionals identify self-care, leisure and social interaction as objectives of their work in the program:

"[...] I think that the objective of my work is pleasure, leisure! [...] There are also few leisure options here that are not linked to the consumption of alcohol" (PEP 4).

"The objective of my work is to promote health, isn't it? For the users, it is also about how leisure is provided, because many come here as a way to unwind, and make friends" (PEP 9). "Hmm... In my opinion, the objective of my work here with these users is to provide them with an additional means of caring for their health....”. (PEP 7).

Considering the predominance of responses that underscore health promotion as the objective of the work of professionals in the program, we sought to assess the perception of the individuals interviewed regarding this construct. This resulted in a concept focused on changing behaviors and lifestyle.

[...] is when we raise awareness among users, using an approach related to health and well -being. And when we talk about well-being, we mean nutrition, physical activity, controlling 
stress, healthy relationships (PEP 18).

To me, health promotion is what you do to promote well-being. So if you eat well, if you walk, engage in exercise. If you live well with your family, go to the doctor regularly, you are promoting health in your life. [...] people have to eat well, live well, and have leisure time. To me, this is health promotion (PEP 5).

On the other hand, some of the individuals revealed a broader viewpoint of the concept of health promotion, involving actors such as the community and public entities.

I think it's serving individuals, providing them not only with information, but making them understand that to be healthy a process is needed. Being healthy is not limited to medication, but is part of a process also linked to professionals from " $x$ " areas, and promoting health is precisely giving people the means to have all this, right? I think that it is also something the State must provide citizens (PEP 5).

Health promotion is giving the means (not necessarily the physical educator, but any health professional, or any professional able to promote good quality of life; for example, a politician can promote health, be concerned about the issue of basic sanitation, the question of urban cleanliness...), and thereby promoting health and providing the means for society to have a good life: the question of nutrition, physical activity, security, all this is directly related to health promotion (PEP 3).

\section{The objects of professional actions in the ASP}

Analysis of the perception of PEPs regarding the object they aim to transform through their work revealed that activities are focused on the individual, the community and functional capacity, evident in the following statements:

Promoting the well-being of people! Ensuring that, above all, they are well [...] both physically and emotionally [...] (PEP 5).

[...] the moment we have a space reserved for physical education in the community and a professional trained in physical education in charge, we fill a previously empty space with activities related to well-being and health [...] (PEP 18).

"We try to recover lost mobility, specifically with physical education involving stretching and resistance exercises, in an attempt at recovering this mobility” (PEP 14).

In addition to identifying the object that professionals aim to transform through actions, the work process is also characterized by the means used to execute these actions. In this respect, analysis of the statements reveals that the professionals describe physical activity as a way of performing their health promotion activities and meeting their work objectives:

[...] if I see that my class can somehow improve their physical fitness, such as muscle tone, cardiovascular performance, then that's what I aim for. I use different strategies. If I see somebody without much motor coordination: "ah, I can't keep up with the aerobics..." then I create strategies for that. [...] (PEP 9).

You use physical exercise as a tool to try and improve the health status of that individual in some way [...] (PEP 6).

In addition to physical activity, there was a perception that instructions (lectures and health education) regarding health-related behaviors are the means to achieve their work objectives. 
[...] educate the user, instruct the user, through information related to physical activity, well -being, health and quality of life [...] (PEP 18).

[...] lectures, round tables... we are always teaching! The quality of life campaigns that you see in health programs, we pass this information on to them. We work a little on this when we provide information to people. [...] (PEP 9).

\section{Products generated by work performed at the Academia da Saúde Program center}

The individuals interviewed were questioned about what they consider products of their work. To that end, they underscored the improvement in physical/functional performance, social interaction and biopsychosocial benefits:

"We can separate this, I think, into two areas: the physical side, where we observe an improvement in flexibility and physical independence, and the mental health side, where users are actually part of a group and from there create a support group, thereby improving mental aspects" (PEP 11).

$[\ldots]$ it's also related to the issue of social interaction, because they come here and use the public space; they know it's important, that it's free, and that it's their right (PEP 9).

Given that ASP is a component of the Primary Care health network and that the intervention products in the program should be linked to other activities at this level of care, this study aimed to determine how PEPs perceive the contributions of their work to the Family Health Strategy program. In this respect, perceptions emerged regarding the lack of contact with ASP teams, or difficulties in coordinating actions with these teams:

"Actually, our activities aren't linked to work in the Family Health Strategy. This is a problem in the program, the lack of multiprofessional work. We are integrated into the network, but not within family bealth itself. That's how I see it". (PEP 5).

"The Family Health Strategy... we don't interact much so it isn't strongly related to work with family health [...] [...] The users there don't come here”. (PEP 2).

\section{Discussion}

Health-related work is characterized, among other things, by the knowledge, instruments and means that professionals use to organize and produce promotion, prevention and care services ${ }^{6}$, seeking to reach predetermined objectives. These objectives define the criteria and parameters to perform the tasks and meet the expected results. In this respect, identifying health promotion and quality of life as the work objectives of physical education professionals in the ASP, in addition to demonstrating the correlation between the perception of workers and the guidelines of the program ${ }^{3,13,14}$ increase the possibilities of achieving the results expected by the ASP, in both the centers and the area.

According to the professionals' discourse, this health promotion is focused on leisure, self-care and encouragement to engage in physical activities, which fulfills some of the specific objectives of the program, such as the production of care and the strengthening of leisure as a health-related activity, as well as raising physical activity in the population ${ }^{3}$. In the case of physical activity, these practices reinforce 
literature findings, indicating that PEPs may increase the likelihood of making the population more active ${ }^{15}$.

The concept of health promotion exhibited by the PEPs of the Metropolitan Region of Recife centers on instructions regarding changes in behavior and lifestyle. With respect to instruction on changing health-related behaviors, this perception is based on health education activities, as reported by the statements of the individuals interviewed. This ability to change behaviors by educational measures and the use of expressions such as "educate the user", as described in a number of statements, denotes a reductionist perception of the concept of promotion. This may be limited to the idea that most sanitary problems are related to lifestyle $^{16}$, which to a certain extent blames individuals for their morbidity. Under this approach, disregarding the factors that are beyond an individual's control, reinforce a tendency to decreasing the responsibilities of the State, making individuals liable for their health ${ }^{17,18}$. According to Traverso-Yépez $(2007)^{16}$, centralizing health promotion as a priority strategy in the ASP should be viewed with utmost caution, in order to avoid a utopian vision of a disease-free society.

However, some of the discourse indicates a broader view of health promotion, involving other actors such as the community and public entities. Although this perception resembles the modern concept of health promotion ${ }^{17}$, which considers the role of all the conditioning and determining factors and actors in the health-disease process, the statements of the professionals do not indicate their part in this process beyond physical activity instruction or health education actions. Health promotion involves acting on conditioning and determining factors by integrating technical and popular knowledge, and mobilizing institutional, community, public and private resources, with a focus on empowerment, co-management and co-responsibility in addressing and resolving the health problems of the population ${ }^{18}$.

With respect to perception of the object of professional intervention, it is important to underscore that the entire work process is conducted in relation to objects on which a transforming action is exerted. These can be raw materials, previously prepared materials or certain personal or social states or conditions ${ }^{7}$. Analysis of PEP discourse reveals that they identify the individual, community and functional capacity of users as objects of their work in the ASP.

According to De Seta and Reis (2009) $)^{19}$, identifying these objects is complex and ascertaining and analyzing them requires three approaches: i) clinical, based on identifying individual and biological problems; ii) epidemiological, based on the ability to identify problems in the population, and; iii) social, whereby problem identification must consider the economic, social and political processes that constitute the social determinants of health. The statements of PEPs seem to include/encompass these dimensions when considering biopsychosocial aspects in the clinical approach, as well as environmental issues and the peculiarities of communities in epidemiological and social approaches.

Analysis of the interviews showed that the PEPs identify physical activity and health education lectures aimed at changing user behavior as objectives of their work in the ASP.

In this respect, our results resemble those reported by Rodrigues et al. (2013) ${ }^{1}$, who conducted a systematic review of PEP performance in Primary Care and observed that they can promote physical activities in this setting, contributing to making individuals more physically active and improving the health and quality of life of the population. However, it is important to underscore that encouragement to adopt more active lifestyles is only one of the 14 specific objectives of the program ${ }^{3}$. 
With respect to educational actions, although lectures can reach a large number of individuals and contribute to encouraging more active and healthier lifestyles ${ }^{20}$, centralizing work around health-related behavior using health education activities, as reported by the professionals, places the user in a passive position in the healthcare process. Actions conducted from this standpoint usually disregard the premise put forth by Freire $(2003)^{21}$, who states that "teaching is not transforming knowledge, but creating possibilities for its production or construction" (p. 22). Moreover, the systematic repetition of simplistic campaigns that show linear cause-effect relationships tends to decrease the chances that these messages will change the behavior of individuals ${ }^{22}$.

The last component of the work process analyzed was the product of the interventions in the program. The responses to this question are aimed at improving physical/functional performance, social interaction and the biopsychosocial benefits provided to users.

In regard to the work product in health, Pires $(2000)^{23}$ found that it is indissociable from the process that produces it; rather, it is the execution of the activity itself. The diversity of the products identified in the discourses of the PEPs may result from the different individual and collective realities of the centers where activities take place, and reflect the complexity of work in the health sector, which, according to Offe ${ }^{24}$, is characterized by unpredictable demand, the moment at which consumption occurs and the type of service that will be offered.

Although the perception of products resembles that contained in the ASP guidelines ${ }^{3}$, a lack of integration was observed between the work performed at the centers and the activities of the family health teams, characterizing a distortion in the program's objectives, health promotion and primary care, which considers the ASP as a strategic element in shaping the health care networks ${ }^{3}$.

This difficulty in implementing teamwork in the ASP was observed by Souza and Loch ${ }^{15}$, in a study with PEPs in Parana state. It is important to point out, however, that this situation significantly compromises the principle of integrality ${ }^{13,14}$, limiting care to PEP activities and fragmenting services, especially since sharing activities between family health teams, Family Health Support Center (FHSC) teams and other players in the area and the Academia da Saúde Program is part of National Basic Care Policy ${ }^{14}$, and the decree that regulates the program itself ${ }^{3}$, which consider them essential activities of health promotion and comprehensive care.

The object, objective and work products of physical education professionals in the ASP are influenced by the sociopolitical and environmental context in which the actions occur. In this respect, a limitation of this study is the impossibility of determining, in loco, how the reality of each center interferes directly or indirectly in these components of the work process. Additional studies using methodological triangulation, such as interviews and direct observation, may reveal aspects related to the planning and execution of actions, between professionals from a same center and between them and other players in the health care process, as well as integration with other sectors of society.

Despite these limitations, analysis of discourses in this study reveals the perception of health promotion as the objective of PEP work, demonstrating coherence between proposals of the Academia da Saúde Program and what Physical Education Professionals intend to achieve with their work. However, the deployment of these activities by encouraging lectures and round tables aimed at changing health-related behaviors does not always correspond to what these professionals identify as products of this work. 
Furthermore, the simplistic perception of health promotion, focused on behavioral changes, and the lack of initiatives to integrate with Primary Care teams demonstrates the fragmented nature of healthcare and a worrisome move away/ break from the proposals of intersectoriality and the perspective of organizing multiprofessional work processes aimed at comprehensive care, as stipulated in ASP guidelines.

The proposal of this study to analyze the PEP's perception regarding the objectives, object of the intervention and the products of their work goes beyond defining the elements contained in the work process as the exclusive prerogative of restricted groups situated in higher positions at institutions. It is also considered important for workers to deliberate on the hierarchical positions of their social production in the healthcare sector, which is marked by actual physical work in the field and, consequently, professional autonomy.

\section{Authors' contributions}

Author 1 participated in preparing the project, developing the methodology, data analysis, writing and revising the manuscript; Author 2 contributed to the research, data analysis and revision of the article. Authors 3, 4 and 5 helped write the manuscript, while author number 5 was the research advisor who helped develop the project, data collection instruments, analyze the interviews and write the manuscript.

\section{References}

1. Rodrigues JD, Ferreira D, Silva P, Caminha I, Farias Júnior JC. Inserção e atuação do profissional de educação física na atenção básica à saúde: revisão sistemática. Rev Bras Ativ Fís Saúde. 2013; 18(1): 5-15.

2. Guarda FRD, Silva RN, Araújo Júnior JLAC, Freitas MIF, Santos Neto PM. Intervenção do profissional de educação física: formação, perfil e competências para atuar no Programa Academia da Saúde. Rev Pan-Amaz Saude. 2014 5(4), 63-74.

3. Ministério da Saúde. Portaria n ${ }^{\circ} 2.681$, de 7 de novembro de 2013. Redefine o Programa Academia da Saúde no âmbito do Sistema Único de Saúde (SUS). Brasília: Ministério da Saúde; 2013. [acessado 01 fev 2014]. Disponível em: http://bvsms.saude.gov.br/bvs/ saudelegis/gm/2013/prt2681_07_11_2013.html.

4. Conselho Nacional de Educação. Parecer CNE/CES n ${ }^{\circ} 058$ / 2004. Estabelece as Diretrizes Curriculares Nacionais para os cursos de graduação em Educação Física. Brasília: Ministério da Educação; 2004.

5. Guarda FRB, Silva RN, Araújo Júnior JL, Santana PR, Santos Neto PM. Incorporação e contribuições dos profissionais de educação física ao Sistema Único de Saúde do Brasil. Tempus Actas de Saúde Coletiva. 2014; 8(3): 185-196.

6. Mendes-Gonçalves RB. Tecnologias e organização social das práticas de saúde: características tecnológicas de processo de trabalho na rede de centros de saúde de São Paulo. São Paulo: Hucitec; Rio de Janeiro: Abrasco; 1994.

7. Faria H, Werneck M, Santos MA. Processo de trabalho em saúde. $2^{\text {a }}$ ed. Belo Horizonte: Nescon/UFMG, Coopmed; 2009.

8. Pernambuco. Gerência de Expansão e Qualificação da Atenção Primária. Relação dos Municípios Contemplados ao Custeio das Ações do Programa Academia da Saúde. Recife: Secretaria Estadual de Saúde; 2013. [acessado 10 nov 2013]. Disponível em: http://geqap. blogspot.com.br/2013/10/monitoramento-nacional-do programa.html.

9. Strauss A, Corben J. Pesquisa Qualitativa: técnicas e procedimentos para o desenvolvimento da teoria fundamentada. $2^{\text {a }}$ ed. Porto Alegre: Artmed; 2008.

10. Minayo MCS. O Desafio do Conhecimento: Pesquisa Qualitativa em Saúde. 10. ed. São Paulo: HUCITEC, 2007. 406 p.

11. Kvale S. Interviews: an introduction to qualitative research interviewing. Thousand Oaks: Sage; 1996. 
12. Oliveira DC. Análise de Conteúdo Temático-Categorial: Uma proposta de sistematização. Rev Enferm. UERJ. 2008; 16(4):569-76.

13. Ministério da Saúde. Secretaria de Vigilância em Saúde. Política Nacional de Promoção da Saúde: PNPS: revisão da Portaria MS/GM nº 687, de 30 de março de 2006. Brasília: Ministério da Saúde, 2015.

14. Ministério da Saúde. Secretaria de Atenção à Saúde. Política Nacional de Atenção Básica. Brasília: Ministério da Saúde; 2012.

15. Souza SCD, Loch MR. Intervenção do profissional de educação física nos Núcleos de Apoio à Saúde da Família em municípios do norte do Paraná. Rev Bras Ativ Fís Saúde. 2011;16(1):5-10.

16. Traverso-Yépez MA. Dilemas na promoção da saúde no Brasil: reflexões em torno da Política nacional. Interface - Saúde, Educação, Comunicação. 2007; 11(22): 223-238.

17. Buss PM. Uma introdução ao conceito de promoção da saúde. In: Czeresnia D, Freitas CEM, (org). Promoção da Saúde: conceitos, reflexões, tendências. Rio de Janeiro: Editora Fiocruz; 2003. p. 39-54.

18. Silva, RN. A Promoção da Saúde no SUS. In: Guarda FRB, SILVA RN, MarizJVB. Atividade Física e Saúde Pública: contribuições e perspectivas. Recife: Editora Livro Rápido, 2011. p 16-23.

19. De Seta MH, Reis LGC. As vigilâncias do campo da saúde: o risco como conceito fundamental e a caracterização dos seus processos de trabalho. In: OLIVEIRA, R.G.; GRABOIS, V.; MENDES, W.V. (org). Qualificação de gestores do SUS. Rio de Janeiro: Fundação Oswaldo Cruz; 2009. p. 219-262.

20. Gomes MDA, Duarte MDFDS. Efetividade de uma Intervenção de Atividade Física em Adultos Atendidos pela Estratégia de Saúde da Família: Programa Ação e Saúde Floripa - Brasil. Rev Bras Ativ Fís Saúde. 2008 13: 44-56.

21. Freire $P$. Pedagogia da autonomia: saberes necessários à prática educativa. $17^{\mathrm{a}}$ ed. São Paulo: Paz e Terra; 2003. p. 22.

22. Radley A. Making sense of illness: the social psychology of health and disease. London: Sage; 1994.

23. Pires D. Reestruturação produtiva e consequências para o trabalho em saúde. Rev Bras de Enfermagem. 2000; 53(2): 251-63.

24. Offe C. Trabalho e Sociedade: Problemas estruturais e perspectivas para o futuro da sociedade do trabalho (v. I: A crise; v. II: Perspectivas). Rio de Janeiro, Tempo Brasileiro; 1989.

CORRESPONDING AUTHOR

FLÁVIO RENATO BARROS DA GUARDA

flaviodaguarda@yahoo.com.br
Rua Cassilândia, no. 331, apto 304

- Várzea, Recife - PE, Brazil.

CEP: $50.740-370$

Tel: 5581 9984-1556 / 8629-5329
RECEIVED 30/11/2015

REVISED $\quad 23 / 01 / 2016$

APPROVED $\quad 25 / 01 / 2016$ 